\title{
Ubiquitous and Smart Learning Paradigm for Preparing Qualified and Skilled Engineers
}

\author{
Mohamed Tawfik, Spanish University for Distance Education (UNED)
}

M.Sc. degree in Electrical \& Electronics Engineering from Spanish University for Distance Education (UNED), Madrid, Spain, and the B.Sc. degree in Electrical Engineering from Ain Shams University, Cairo, Egypt, in 2011 and 2008 respectively. Visitor researcher at the Faculty of Engineering \& IT, University of Technology, Sydney (UTS), Australia, in 2012. He is an IEEE member since 2009. Actually, he is a research associate in Electrical \& Computer Engineering Department (DIEEC) at UNED. He is author $\backslash$ co-author of more than 25 publications; including conference papers, book chapters, and journal articles on remote laboratories. He is collaborating in several researching projects among them NSF Catalyzing New International Collaborations proposal "Building an Ecology of Online Laboratories".

\section{Dr. Elio Sancristobal, uned \\ Dr. Sergio Martin, UNED - Spanish University for Distance Education}

Sergio Martin is PhD by the Electrical and Computer Engineering Department of the Industrial Engineering School of UNED. He is Computer Engineer in Distributed Applications \& Systems by the Carlos III University of Madrid (UC3M), receiving Honor marks in his final project. Technical Computer Engineer by the Polytechnic University of Madrid (UPM). He teaches subjects related to microelectronics and digital electronics since 2007 in the Industrial Engineering School of UNED. He has participated since 2002 in national and international research projects related to mobile devices, ambient intelligence, and location-based technologies as well as in projects related to "e-learning", virtual and remote labs, and new technologies applied to distance education. He has published more than 100 papers both in international journals and conferences, being awarded in 2009 with the Best Paper Award in the Fourth International Multi-Conference on Computing in the Global Information Technology and in 2007 with the Jean Peperstraete award for the Best Paper in the 18th Annual Conference on Innovation in Education for Electrical and Information Engineering. He is IEEE and ACM member. He joined in 2010 the Advisory Committee of the IEEE Spanish Chapter of the Education Society, and in 2009 the Advisory Committee of the IEEE Technology Management Council of Spain. He also participates as technical reviewer for several international journals and conferences.

\section{Miss Rosario Gil, Spanish University for Distance Education (UNED)}

Rosario Gil has a PhD in Industrial Engineering from Spanish University for Distance Education (UNED) and a Master and Bachelor in Telecommunication Engineering from The Alcalá de Henares University (Madrid). She got a grant in the Electrical and Computer Engineering Department of UNED in 2005 and since December 2010 she is an assistant professor. Her research interest is the integration of different biometric techniques in educational environment by providing them with security and access control.

\section{Alberto Pesquera, UNED}

Computer Science Engineer by Spanish University for Distance Education (UNED). He was a collaborator member of Telematic Laboratory of UNED (Telelab) in systems of Computer Supported Cooperative Work (CSCW). Nowdays is working for Innovation and Technological Development Centre of UNED (CiNDETEC). He is an expert in Learning Management Systems (LMS) and Web development applications. Currently, he is collaborating in a research project of Open services integration for distributed, reusable and secure remote and virtual laboratories (s-Labs).

Prof. SANTIAGO MONTESO FERNANDEZ, UNED

Mr. Félix García Loro, Predoctoral fellow

(C)American Society for Engineering Education, 2013 
Industrial Engineering degree from the Spanish University for Distance Education (UNED). Assistant teacher in Wind Energy Expert Course (Continuing Education, UNED). Managing AVIP advanced videorooms (UNED) from 2010 to 2012. Tutor and Intercampus Tutor of several Department subjects in last years.

\section{Dr. Maria José Albert Gomez, UNED}

Dra. Pedagogy. Teacher in Education Theory and Social Pedagogy Depatment of UNED. Madrid Spain

\section{Prof. GABRIEL DIAZ ORUETA, UNED}

Gabriel Díaz Orueta has a doctoral degree in Physics from the Sciences Faculty of Universidad Autonoma de Madrid. He worked for 10 years for different ICT companies as DEC or Cisco. He has several different industry certifications, as those of Cisco, HP, Microsoft and ITIL or ISO 20000. He currently works, as an Associate Professor, for UNED (Spanish University for Distance Education) inside the Electrical and Computer Engineering Department. He also is the CEO of his own company, ADSO Consultoría y Formación, dedicated to learning and consulting services. He is author (or co-author) of different publications, technical, research and teaching books and papers for journals and conferences as well as multimedia materials and radio programs. He works as researcher in numerous projects, specially related with different new techniques in the e-learning arena and with different areas of Information Security for network, systems and organizations. He is a Senior Member of IEEE, Chairman of IEEE's Spanish Chapter of Education Society,

\section{Prof. Nevena Mileva, Plovdiv University "Paisii Hilendarski"}

Nevena Mileva received her M.S. Degree in Electronics and the Ph.D. in Computer technologies in education from Technical University of Sofia, and the M.S. Degree in Educational Technology from the University of Twente, the Netherlands. She is currently associate professor and head of ECIT Department and lecturer on Information technology. She was engaged with utilization of IT in education, development of methods for Web-based engineering education, development of Internet-based PSS. She has over 35 papers and three books. She is involved currently in the instructional design and evaluation of ODL materials.

Mr. Mihail Milev

Prof. juan peire

Prof. Manuel Castro, Universidad Nacional de Educacion a Distancia

Manuel Castro, Electrical and Computer Engineering educator in the Spanish University for Distance Education (UNED), has an industrial engineering degree from the ETSII (Industrial Engineering School) of the Madrid Polytechnic University (UPM) and a doctoral engineering degree from the same University. He has received the Extraordinary Doctoral Award in the UPM and the Viesgo 1988 Award to the Doctoral Thesis improving the Scientific Research about the Industrial Process Electricity Application, as well as the 1997 and 1999 years UNED's Social Council Award for the Best Didactic Materials in Experimental Sciences and the 2001 Award for the Innovative Excellence in Teaching, Learning \& Technology from the Center for the Advancement of Teaching and Learning. He works as researcher, coordinator and director in different projects, ranging from systems applications of simulation techniques, solar system and advanced microprocessor system simulation to telematics and distance learning applications and systems, as well as computer-aided electrical engineering (CAEE), acting now as and senior Technical Director. He is now with the UNED (Spanish University for Distance Education) as Professor of Electronics Technology inside the Electrical and Computer Engineering Department. He was previously UNED's New Technologies Vice-Rector, UNED's Information Services Center Director and Research, Doctorate Vice-director and Academic Affairs Vice-director of the Engineering School at UNED and Director of the Department. He worked during 5 years in Digital Equipment Corporation as senior system engineer. He publishes different technical, research and teaching books and articles for journals and conferences 
as well as multimedia materials and radio and TV programs. He belongs to the organizing committee of IEEE EDUCON, IEEE FIE (International and Europe Chair, 2000-2006), ISES, TAEE and SAAEI conferences as well as program and planning committees' member and reviewer and chairman of several ones. He was co-chair of the conference EDUCON 2010 (Engineering Education Conference), TAEE 2010 (Tecnologías Aplicadas a la Enseñanza de la Electrónica) and ICECE 2005 (International Conference on Engineering and Computer Education). Is co-chair of the conference FIE 2014 (Frontiers in Education Conference) to be organized in Madrid, Spain, by the IEEE and the ASEE. He is co-editor of IEEE-RITA (Revista Iberoamericana de Tecnologías del Aprendizaje) and of the Electronic Journal of Spanish Chapter of the IEEE Education Society. He is Fellow member of IEEE (for contributions to distance learning in electrical and computer engineering education) and member of the Administration Committee (AdCOM) (2005-2012) of the IEEE Education Society and Vice-chair (2011-2012) of the IEEE Education Society; Founder and Past-Chairman (2004-2006) of the Spanish Chapter of the IEEE Education Society, and Chair of the IEEE Spain Section (2010-2011). He has been awarded with the IEEE EDUCON 2011 Meritorious Service Award (jointly with Edmundo Tovar), of the EDUCON 2011 conference; 2010 Distinguished Member Award of the IEEE Education Society; 2009 Edwin C. Jones, Jr. Meritorious Service Award of the IEEE Education Society; with the 2006 Distinguished Chapter Leadership Award and for the collective work inside the Spanish Chapter of the IEEE Education Society with the 2011 Best Chapter Award (by the IEEE Region 8) and with the 2007 Chapter Achievement Award (by the IEEE Education Society). He is Vice-President of the Board of the Spanish International Solar Energy Society (ISES). 


\title{
Ubiquitous and Smart Learning Paradigm for Preparing Qualified and Skilled Engineers
}

\begin{abstract}
In this paper an innovative approach for preparing qualified and skilled engineers is presented. The paper reports on a new inter-institutional master's degree program in Information and Communication System (ICS) that is delivered online and across five European institutions. The program has been developed under the European grant "Remotelabs Access in Internet-based Performance-Centered Learning Environment for Curriculum Support (RIPLECS)", and it aims to mitigate the deficit in qualified professionals and technical job-specific skills. On the other hand, the program copes with the predominant students' lifestyles by eradicating distance and time restrictions. The program is administrated and delivered through an online learning platform (DIPSEIL) that enables world-wide distribution of learning resources by utilizing multiple Web servers at partners' institutions within a single network topology. Access to remote laboratories as an integral task within the subjects, in order to guarantee the acquisition of practical competences as well as the theoretical ones, is the main novelty of the program, making it a unique approach of its kind. The development and the organization of the program are discussed in this paper. This is followed by a description of a selected state-of-the-art remote laboratory-Virtual Instrument Systems in Reality (VISIR)-that is going to be adopted in one of the master's subjects- Power Supplies for Information and Communication Technology (ICT). VISIR is a remote laboratory for wiring and measuring electronic circuits on a breadboard. Some previous results from the system implementation are presented along with the scheduled practices to be done within the new master's degree program.
\end{abstract}

\section{Introduction}

Unskilled and non-qualified graduates are considered to be two of the most common threats that have been associated with most of the official engineering curricula around the world. While the theoretical content is always being emphasized and well-imparted, the practical content is usually dismissed or ignored. This is, substantially, owing to the high cost of the equipment and laboratory personnel. The time and mobility availability are other important factors as well. Most of the engineering curricula are not oriented, to some extent, to labor sectors' characteristics. As a result, most of the graduates struggle during their shift from the academia to the industrial real world. In order to mitigate this issue, some enterprises have endeavored to prepare engineers, and to help them to acquire specific skills demanded by the labor market, by means of sponsored training courses. However, this solution is not affordable for the majority of graduates.

The advent of computer and information technologies has revolutionized the learning process and has yielded new learning models known as e-learning, blind learning, distance learning, or online learning, which allows efficient learning that is adaptable to predominant students' 
lifestyles without time or distance constraints. E-learning was confined to theoretical content from its inception until the appearance of remote laboratories few years later, in the late 1990s. Remote laboratories allow managed access to, and control of real, instruments online in real time. Moreover, they promote collaboration between universities by sharing their laboratory facilities, which results in the offset of cost and increase of experiments range and availability. Thus, offering e-learning including modules that provide access to remote labs, by far, is the most ubiquitous, low-cost, and adaptable solution for defying the deficit of qualified and skilled engineers.

In this respect, a unique initiative, in form of a new inter-institutional European online master's degree program in the Information and Communication Systems (ICS) curricula, which leverages e-learning and remote laboratories technologies, is presented in this paper, assuring ubiquitous and smart paradigm for preparing qualified and skilled engineers. The program has been developed under the European grant "Remote-labs Access in Internetbased Performance-Centered Learning Environment for Curriculum Support (RIPLECS)", and it is oriented to labor market needs. Real-world experiments are accessed remotely along with a pool of online learning resources that is administrated by a learning platform (DIPSIEL) previously developed by the project partners. The program is delivered by five European institutions. Each partner contributes with at least a subject, in addition to access to a remote laboratory.

The rest of the paper is structured as follows: Section II discusses the development and the organization of the new inter-institutional European online master's degree program; Section III discusses the role of remote laboratories in the new master's degree program; Section IV presents a case study and describes a state-of-the-art remote laboratory-Virtual Instrument Systems in Reality (VISIR)-for wiring and measuring electronic circuits on a bread board, and which is going to be adopted in one of the new master's subject-Power Supplies for Information and Communication Technology (ICT); Section V provides some previous results from VISIR implementation along with the scheduled practices to be done within the new master degree program; and finally a conclusion is drawn in Section VI.

\section{New Inter-Institutional European Online Master Degree Program}

The new inter-institutional European online master degree program has been developed under the European grant RIPLECS [1]. The idea was to deliver a telematics-based educational and training program for ICT in Europe, which is labor-oriented and includes remote access to laboratories as an integral task in most of the subjects. RIPLECS is the successor of the previous projects DIPSEIL $[2,3]$ and IPLECS $[4,5]$. The DIPSEIL project provides an integrated master program in a platform for open and easily accessible learning resources, which answer to the global strategy for the effective integration of ICT in higher education, realizing the effective virtual mobility of students and staff. A distributed performancecentered adaptive Learning Management System (LMS), for IT, telecommunication, microelectronic and electronic courses, was set-up, and five DIPSEIL servers in four countries in Europe has been installed, as shown in Figure 1. 


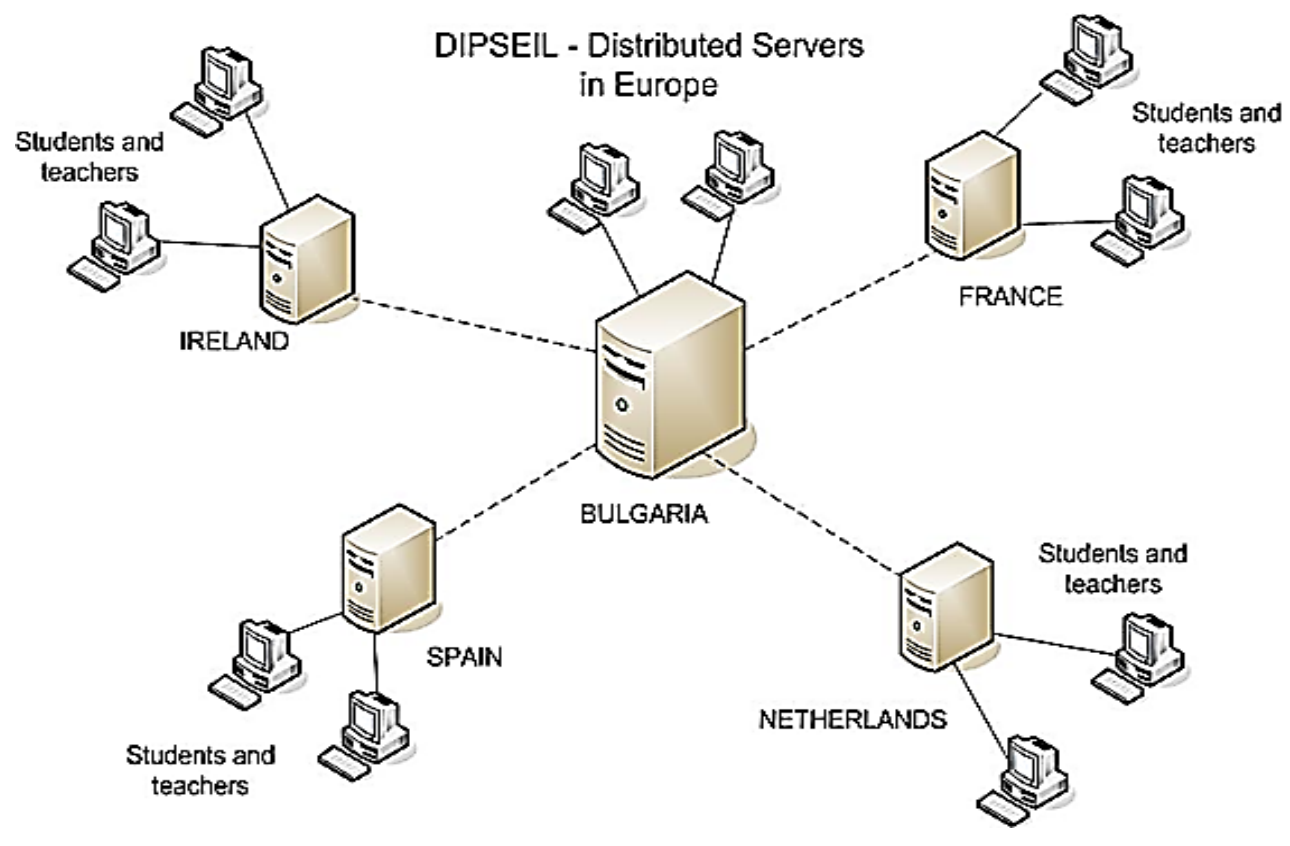

Figure 1. Five DIPSEIL servers in four European countries.

In addition, a pool of learning resources on DIPSEIL database in four different languages is provided. An extension to the DIPSEIL project was the IPLECS project that has proved that developed performance-centered reusable and open course learning materials could be used to support university curricula in the field of engineering education. Under the IPLECS project, almost 50 performance-centered courses in five languages has been add to the DIPSEL platform and a whole Master degree program has been implemented at one university and some courses from the program has been implemented at the other four universities. The aforementioned carried out projects and the acquired experiences by the partners returned strong positive results, however, the feedback from the employers of graduated students and from a number of enterprises in the sector during the implementation of courses was that more practical skills are expected and more laboratory practices are necessary. The preliminary analysis has also shown that whilst there already exists considerable ICT multimedia content on web servers, there does not yet exist a telematics based educational and training service for ICT in Europe. In response to these needs, the partners have launched the RIPLECS project to create such a telematics-based educational and training service for ICT in Europe by developing remote accessed laboratories in multiple disciplines. The RIPLECS project goals are in accordance with the European Higher Education Area (EHEA) objectives for 2020, according to the Bologna process [6]. The program is delivered by five European institutions. Each partner contributes with at least a subject, in addition to access to a remote laboratory. The project partners are:

- Spanish University for Distance Education (UNED), Spain.

- University of Plovdiv (PU), Bulgaria.

- Cork Institute of Technology (DEIS), Ireland.

- Technical University of Sofia (TUS), Bulgaria. 
- Graz University of Technology (TUGraz), Austria.

The master program is targeted to engineers, technicians and scientists with interest on up-to date topics in the area. This master-degree title gives a deeper and complete formation in the ICS research areas, as well as development activities linked to professional sectors. Recent advances in electronics components and systems, advanced design, advanced communication electronic systems or application techniques in industrial sectors will be emphasized. Students will acquire skills focused on industrial field like production organization, design of products, processes and installations, quality management or multidisciplinary teams' management. Additionally, different training and educational activities focused on research processes related to the electronics engineering field will be carried out.

The program will start in the academic year 2013/2014 and will be delivered as many years as the labor market needs ICT specialists and students want to enroll for the master degree curricula. Enterprises in the sector of ICT need design and production engineers and scientists skilled in more than just one area of research which should be able to work with the newest technological equipment. Thus, part of the project management will include contacting and collaboration with enterprises in the sector to respond to the labor market needs.

The curricula courses are based on ECTS and it will be conducted and accredited initially in Spain, by the Spanish ANECA accreditation Agency [7], as part of the official courses conducted at UNED. This is owing to the vast historical experience of UNED in delivering online educational programs-UNED is the second distance education university in the Europe in terms of number of "online" enrolled students [8] after the Open University in United Kingdom, the actual number of enrolled students is 260.079. In addition, a certification from all partner universities will be included. The consortium unites universities teaching engineering and science, and open universities. It encompasses members from four European countries with four different languages and from different application domains, including mathematics, physics, microelectronics, information technology and telecommunications.

The master program is of one year ( 2 semesters) and 60 ECT, and is composed of three modules; fundamental module, specialized module, and final project module. The subjects are of 5 ECT, and the final project is of 10 ECT. All subjects will be taught in English and any student around the world could be registered and enrolled in the master. Moreover, remote laboratories will form an integral part within the subjects of the master program. The program curricula is organized as shown in Table 1. 
Table 1. Contents of the new master degree program.

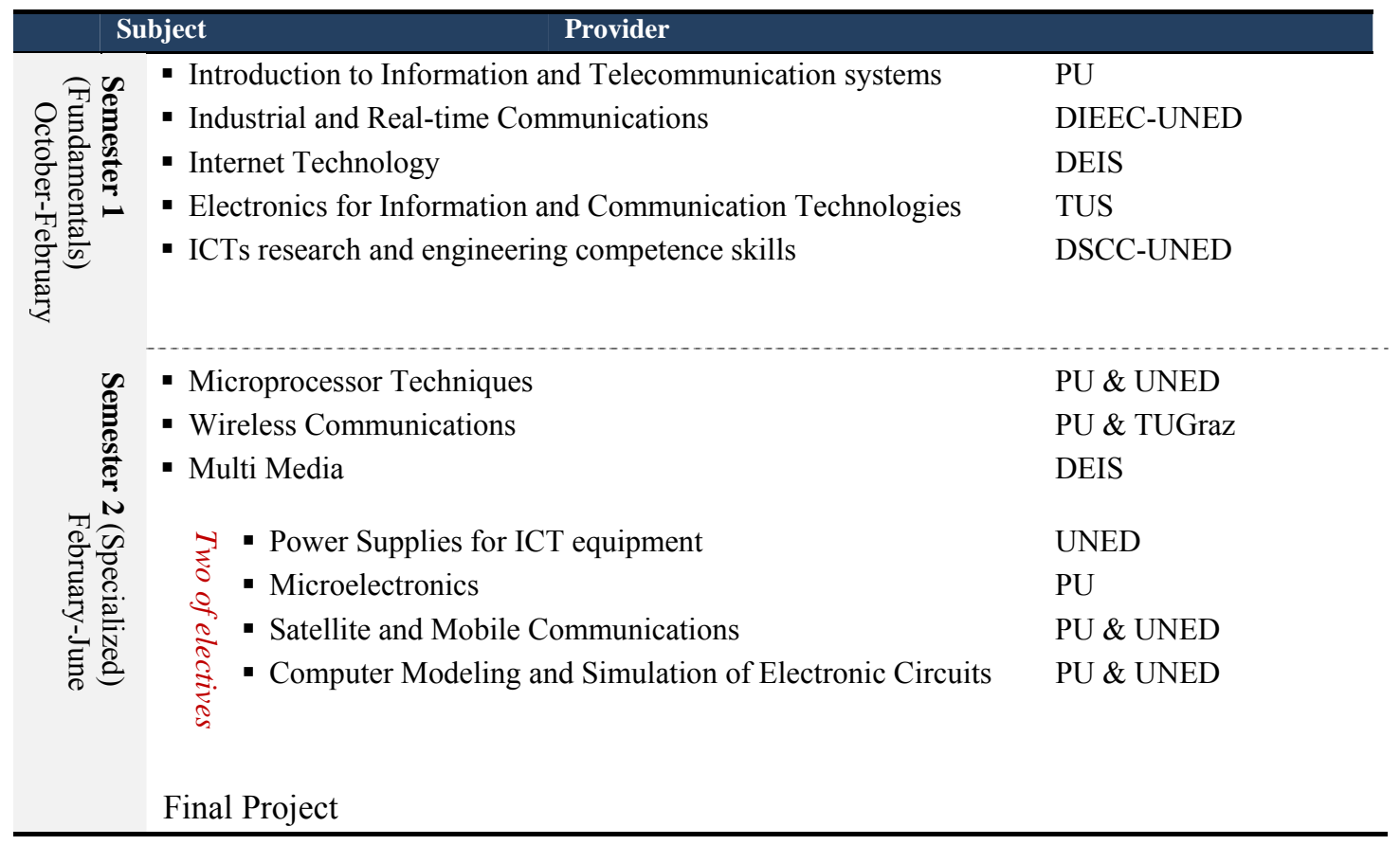

RIPLECS relies on DIPSEIL platform; a distributed LMS, previously developed by the project partners, which enables world-wide distribution of learning resources and remote lab experiments access. A DIPSEIL server will be installed at each partner's institution within a single network topology. Thus, instructors at each institution could take the advantages of employing learning resources and lab experiments and present it in their native language and personal educational point of view.

\section{Remote Laboratories and their Role in the Master Program}

Remote laboratories [9-14] are those laboratories that can be controlled and administrated online. They are distinguished from virtual laboratories as they are dealing with real physical equipment. Several initiatives have launched in order to integrate remote laboratories with heterogeneous educational platforms [15] such as

1. LMSS [16-18]: facilitates reusing preexisting services provided by legacy LMSs during remote lab sessions such as administration, profile and roles, scheduling, synchronous and asynchronous communication tools.

2. Remote Laboratory Metadata Repositories (RLMRs) [19]: provides information about dispersed remote laboratories installed at universities around the world. This information might be classified into categories such as language, discipline, experiment type, etc.

3. Remote Laboratory Management Systems (RLMSs) [20-27]: promotes interinstitutional sharing of remote lab facilities through a common online portal that provide access and administration to its integrated remote lab systems, which might be installed at different universities. 
The inclusion of Internet accessible labs within the master degree program will definitely promote cross-institution co-operation and offset costs and burdens. Students at one university will access remotely to a laboratory made accessible by another university. The partner organizations will share the cost of an expensive laboratory and physically establish it at a convenient location. Students will have a possibility to have practical work in labs in different countries, in which labs are usually very expensive- in some cases they are even unavailable for public universities. So far, the developed remote labs to be integrated in the master's subjects are the following:

- Remote Lab for Wireless Sensor Networks (WSNs): for configuring and programming WSNs online. This is a remote lab from TUGraz for the subject "Wireless Communications".

- Remote Lab for GSM and 3G Telecommunications: for measuring the radiation patterns of various types of antennas to get a clear picture on their radiation characteristics, and measuring characteristics of wave propagation in mobile communications identifying parameters such as fading, phase delay, standing wave, and Doppler frequency. This is a remote lab from PU for the subject "Wireless Communications".

- Embedded Systems Remote Labs: Embedded systems remote labs are a collection of mounted boards such as Field-programmable Gate Array (FPGA), Microprocessor, and microcontroller, which are totally administrated, controlled, and monitored online for education and experimentation boards. The students use these types of boards in order to program them online by programming languages such as VHSIC hardware description language (VHDL) and to monitor the results through a connected Webcam. This is a remote lab from UNED for the subject "Microprocessor Techniques".

- Virtual Instrument Systems in Reality (VISIR): VISIR is a remote laboratory for wiring and measuring electronic circuits on bread board online. This is a remote lab from UNED from the subject "Power Supplies for ICT". The system description is disused broadly in the next section.

In addition other remote laboratories are still under-development due to be ready by the commencement of the academic course 2013-2014.

\section{Virtual Instrument Systems in Reality (VISIR)}

VISIR [28] is a remote laboratory for wiring and measuring electronics circuits on a breadboard. The user designs and constructs her circuit via PC-mouse on a seamlessly simulated workbench that resembles the real lab elements and components. Once the designed circuit is submitted, it is first sent to be verified then to be wired and measured by real instruments, and finally, it is received by the user on her PC-screen in real-time, Figure 2. 

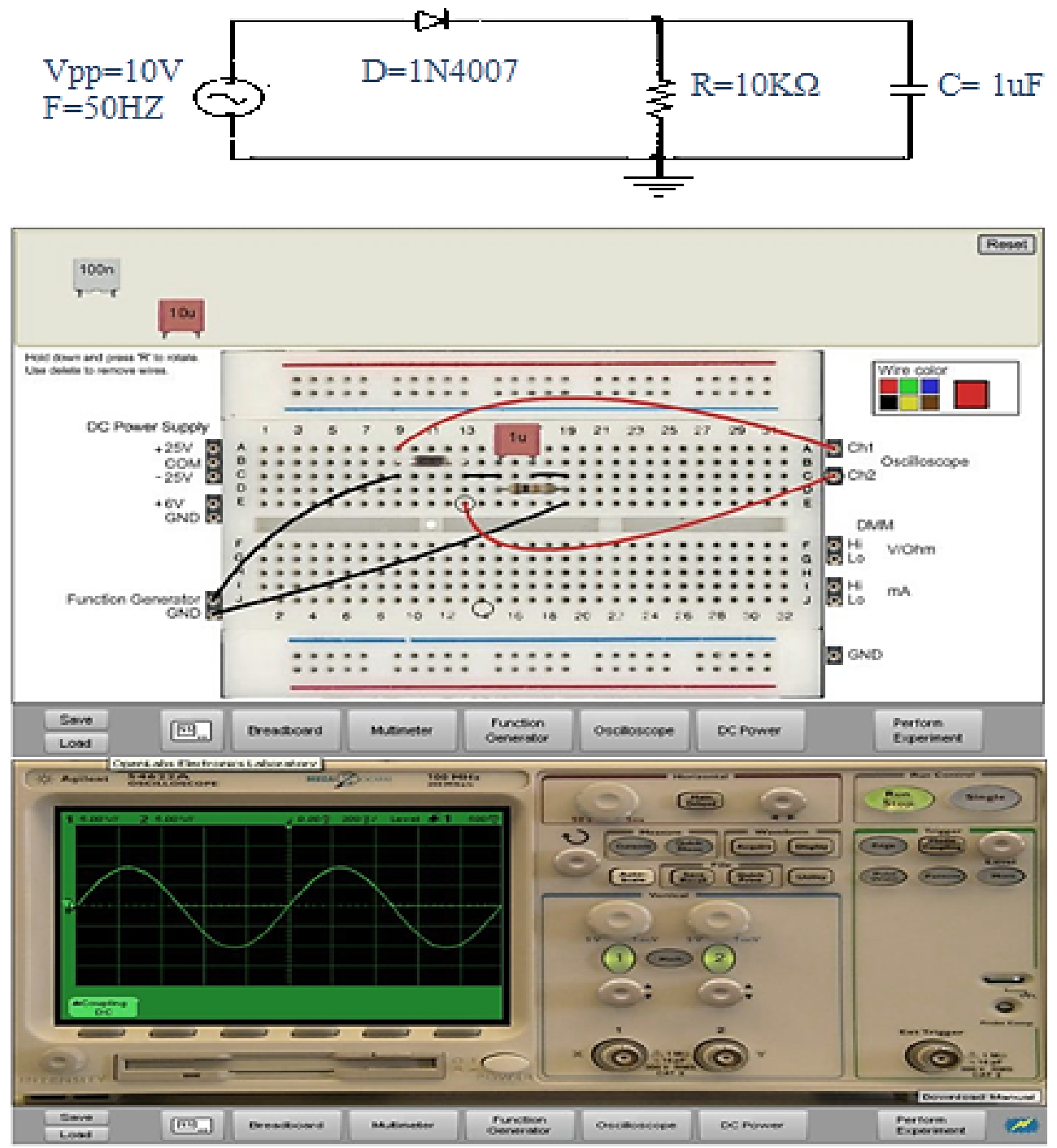

Figure 2. Half wave rectifier circuit mounted using VISIR.

The instrumentation platform is based on PXI from National Instruments (NI). The NI PXI platform consists of instrument module cards, a controller card and a chassis into which all the cards are plugged. The terminals of the NI PXI-modules are connected to a relay switching matrix that comprises the components. The relay switching matrix acts as a circuitwiring robot that connects the terminals with the components. The whole operation cycle can be summarized as shown in Figure 3. 


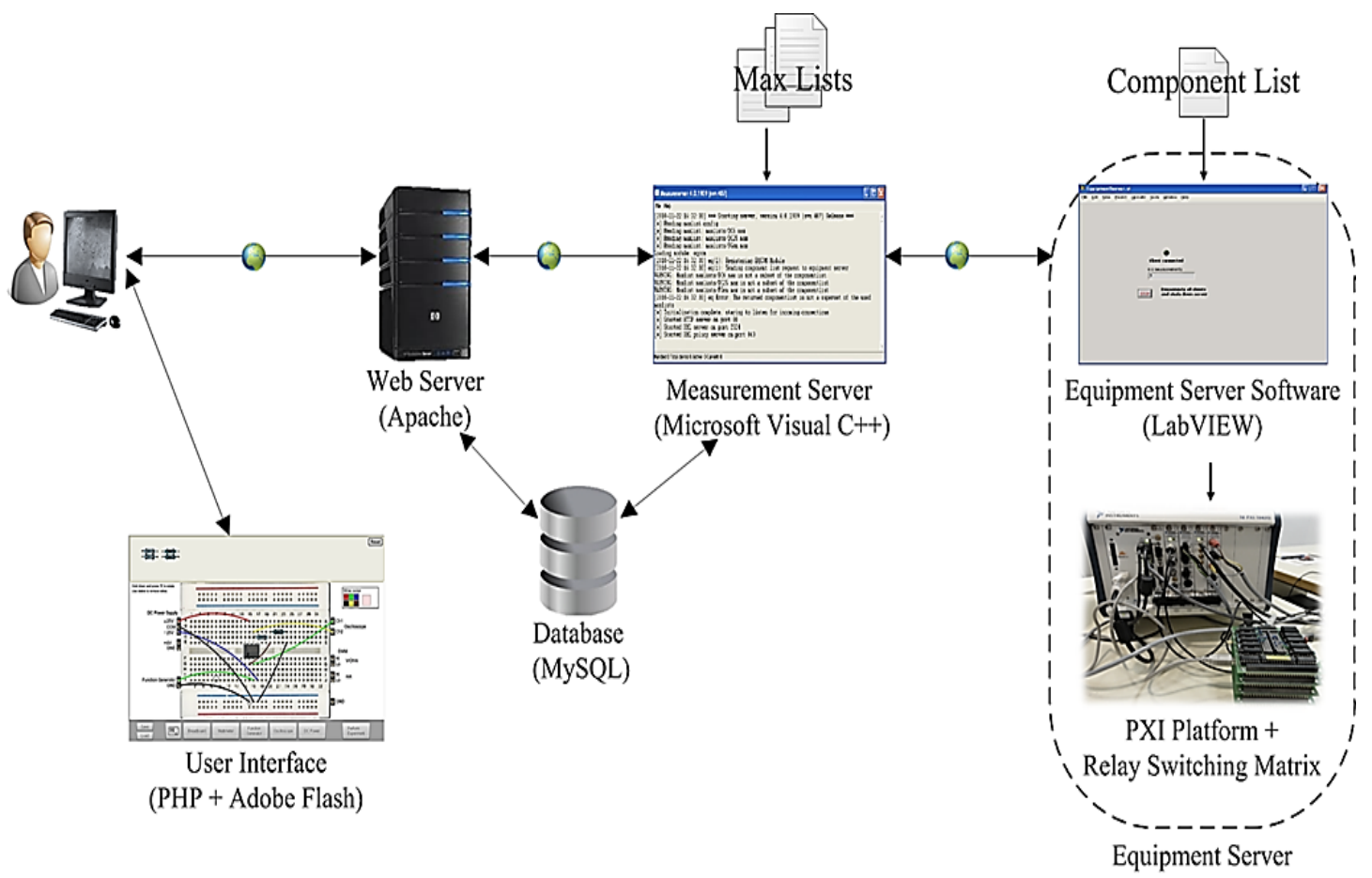

Figure 3. The overall operation cycle of VISIR.

The user interface is the frontal web page of VISIR that handles all the administration, access, and authentication process. It provides many features similar to those provided by a LMS in order to facilitate the implementation of VISIR in the learning process. The experiment client is a simulated workbench embedded in the HTML code of the user interface. The user chooses the instrument interface with which she is familiar regardless of the model or the manufacturer and starts to design and wire her circuit on a simulated breadboard by clicking and dragging the simulated components and wires with her PCmouse. Once the user gets her circuit ready, with all the instrument values adjusted, and clicks on the "perform experiment" button. The experiment client sends the designed circuit with all the adjustments and the configurations to the measurement server through the experiment protocol (an XML-based protocol transported over the TCP/IP model). The measurement server receives the measurement requests from the experiment client and verifies the circuit's design against the maximum permitted values defined in the max list file (prepared by the teacher or the administrator) in order to avoid hazardous circuits or any damage that may be caused to the real instruments. Afterwards, the measurement server starts to send the requests to the equipment server which consists of the PXI platform and the relay switching matrix. The equipment server software is an application developed by LabVIEW and installed in the NI PXI-controller. It receives validated sequential experiment protocol requests from the measurement server executes it through the connected instruments. After that, the results return back to the client PC-screen with the same sequence. The results are represented in the form of measurements on the simulated instruments. The component list file of the relay matrix is inserted inside the equipment server software folder to define the available components to the software. 


\section{Implementation and Practices}

VISIR has been successfully implemented and deployed in the undergraduate engineering practices at Institute of Porto (ISEP), University of Deusto, and UNED [28]. The overall results were satisfactory. Several electronic circuits' practices have been carried out by VISIR without any inconvenient. These practices include:

- Half-wave rectifier with and without a filter.

- Inverter and non-inverter operational amplifier.

- Regulator with zener diode.

- Common emitter and common collector BJT.

At ISEP, VISIR has been deployed in a course of more than 270 students enrolled without many irregularities. The students stated that they did not feel that it helped with their motivation but they would like to extend its utilization to other subjects. They also felt that a formal tutorial could have been helpful. At university of Deusto, VISIR was accepted among the students as a useful tool for practical sessions; the students who had used it gained more self-confidence when they started using the real lab, even though, their first time was through a remote lab. On the other hand, the students considered it as a support tool, not a total substitution for real labs.

At UNED, during the academic year 2009/2010, the students of the subject "Electronic Circuits and components", a first year subject of the Technical Industrial Engineering career in Spain, used the VISIR installed at University of Deusto, thanks to an agreement between both universities. The goal was to evaluate the system performance and to check its accuracy and sustainability when it comes to real time deployment. About 40 enrolled students were using the VISIR of Deusto during two entire days without any problems or inconvenience. The students could repeat their experiments varying the values all the time they needed during the two days. In other words, the results were very satisfactory and the system was proven to be sustainable. Many of these students stated that they would like to use VISIR for electronic circuit practices of other subjects. Many students also stated that it would be better to use VISIR to make the first approach towards the instruments and, afterwards, repeat the same practices in the real laboratory. Owing to this positive perception, the Electrical \& Computer Engineering Department at UNED decided to install its own VISIR for the undergraduate electronic circuit's practices. The department installed a VISIR in December of 2010. The system was in operation starting from the academic year 2010/2011 and was used as a mandatory pre-laboratory work for students of the subject, "Foundations on Electronic Engineering"- a subject within the new Electronic Engineering grade of Bologna that was recently applied in Spain. The goal was to use VISIR to take the first approach to the instruments and the typical ways of work in a real electronics laboratory. Afterwards, the students would repeat the same practices in the real laboratory at the department. This procedure allowed the students to gain more efficient experimentation skills during their first electronics practices. At the end of the course, a survey was conducted among all the enrolled students (64 students) in that subject. The survey encompassed questions in terms of learning outcomes, sense of reality, and performance. The survey results are shown in Table 2. 
Table 2. Survey on VISIR Deployment at UNED (2010/2011).

Question

Score

(out of 5)

Average

(\%)

Q.1. It helped me to understand the subject contents?
Q.2. It was useful for trying many circuits without any
Q.3. I recommend it to be used in other subjects?

3.05

77.53

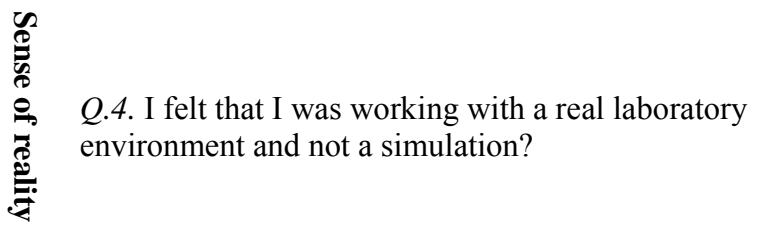

3.69

73.8

总

Q.5. It was responding without time delay?

4.49

Q.6. There were no software bugs or access errors?

4.11

As seen in the table, the performance of the system is notably high. The sense of reality could be better - this may owe to the lack of live view (Web cam) of the equipment, since in VISIR student only see the simulated workbench even though she is manipulating a real one - but it is still relatively high for being a remote laboratory. In general terms, VISIR was definitely feasible and students enjoyed the experience and gained a higher motivation for learning.

Owing to the positive results and perception after utilizing implementing VISIR in practices for two consecutive years, VISIR will be implemented in the practices of the subject "Power Supplies for ICT" within the new master degree program. The subject provides knowledge about fundamentals of power electronics, filters, AC distributions lines, reliability and maintainability, safety, and low volt electric systems installation. Enrolled students form different European countries will be able to enjoy this experience and realize the subject's practices online using VISIR. The scheduled practices to be realized are the following:

- Half-wave Rectifier Circuit

- Diode Zener Voltage Regulator

- Full Wave Bridge Rectifier Circuit

- RC High-Pass Filter Circuit

- RC Low-Pass Filter Circuit

- RL Low-Pass Filter Circuit

- RL High-Pass Filter Circuit

Two manuals have been prepared along with the subject materials: a general descriptive manual about VISIR and a practice manual. Each student will access to VISIR in the scheduled time specified by the teacher and with the same Dipseil platform credentials using the "single sign-on" technique. 


\section{Conclusion}

The new inter-institutional European online master degree program is a step forward towards more a better education paradigm that aims to address the labor market needs, the shortness in skilled and qualified graduates, and the EHEA objectives for 2020, according to the Bologna process. The variety of partners form different European institutions would enrich the experience and augment the program contents. The program is conducted by European partners, however, being online, it would include students from all over the world and it will be compatible with different life styles of the predominating students. The integration and adoption of remote laboratory work as an integral task of most of the subject is another asset that paves way for inter-institutional co-operation and cost cutting by sharing expensive lab facilities. Putting all these factors together makes the program unique of its kind. Thus, its successful implementation would pave the way for further initiatives of this kind, which is not only confined neither to ICS nor Engineering either, but for many other disciplines of science.

\section{Acknowledgment}

Authors would like to acknowledge the support of the following projects: e-Madrid (S2009/TIC-1650), RIPLECS (517836-LLP-1-2011-1-ES-ERASMUS-ESMO), PAC (517742-LLP-1-2011-1-BG-ERASMUS-ECUE), EMTM (2011-1-PL1-LEO05-19883), MUREE (530332-TEMPUS-1-2012-1-JO-TEMPUS-JPCR), and Go-Lab (FP7-ICT-2011$8 / 317601)$.

\section{References}

[1] (2012, October 30). RIPLECS Project - Remote-labs access in Internet-based Performancecentred Learning Environment for Curriculum Support. Available: http://riplecs.dipseil.net/

[2] (2012, October 30). DIPSEIL Team web-page. Available: http://dipseil.net/

[3] E. Lopez, E. Sancristobal, S. Martin, G. Diaz, M. Castro, J. Peire, J. M. Gomez, and P. Lopez, "Internet-based teaching evolution in Computer Architecture," in Frontiers in Education Conference, 2008. FIE 2008. 38th Annual, 2008, pp. T2B-15-T2B-20.

[4] C. Martinez-Mediano, M. Castro, N. Rioperez, G. N. Mileva, S. Stoyanov, S. Tzanova, W. Kicken, Diaz, E. Sancristobal, S. Varela, and S. Martin, "Internet-based performance-centered learning environment for Curriculum Support (IPLECS) and its application in mLearning," in Education Engineering (EDUCON), 2010 IEEE, 2010, pp. 819-824.

[5] (2012, October 30). IPLECS - Internet-based Performance-centered Learning Environment for Curriculum Support Available: http://iplecs.dipseil.net/

[6] (2012, October 30). The Bologna Process 2020 - The European Higher Education Area in the new decade. Available: http://www.ond.vlaanderen.be/hogeronderwijs/bologna/conference/documents/Leuven_Louva in-la-Neuve Communiqu\%C3\%A9 April 2009.pdf

[7] (2012, October 30). ANECA. Available: http://www.aneca.es/

[8] (2012, October 30). Spanish University for Distance Education (UNED): Statistics. Available: 
http://portal.uned.es/portal/page?_pageid=93,510355,93_20540449\&_dad=portal\&_schema $=$ PORTAL

[9] M. Castro, E. Sancristobal, S. Martin, R. Gil, M. Tawfik, A. Pesquera, M. J. Albert, G. Diaz, and J. Peire, "One Step Ahead in the Future of Labs: Widgets, Ubiquity and Mobility," presented at the Remote Eng. \& Virtual Instrum. (REV) 2012, Bilbao, 2012.

[10] E. Sancristobal, S. Martín, R. Gil, P. Orduña, M. Tawfik, A. Pesquera, G. Diaz, A. Colmenar, J. García-Zubia, and M. Castro, "State of art, Initiatives and New challenges for Virtual and Remote Labs," presented at the 12th IEEE International Conference on Advanced Learning Technologies (ICALT), Rome, Italy, 2012.

[11] M. Tawfik, E. Sancristobal, S. Martin, G. Diaz, and M. Castro, "State-of-the-art remote laboratories for industrial electronics applications," in Technologies Applied to Electronics Teaching (TAEE), 2012, 2012, pp. 359-364.

[12] M. Tawfik, E. Sancristóbal, S. Martín, C. Gil, A. Pesquera, S. Ros, R. Pastor, R. Hernández, G. Díaz, J. Peire, and M. Castro, "Towards a Better Deployment of Remote Laboratories in Undergraduate Engineering Education," in Using Remote Labs in Education: Two Little Ducks in Remote Experimentation, J. G. Zubía and G. R. Alves, Eds., ed Bilbao: University of Deusto, 2011.

[13] M. Tawfik, E. Sancristobal, S. Martin, R. Gil, G. Diaz, J. Peire, and M. Castro, "On the Design of Remote Laboratories," in Global Engineering Education Conference (EDUCON), IEEE, Marrakesh, 2012, pp. 1-6.

[14] M. Tawfik, E. Sancristobal, S. Martin, R. Gil, A. Pesquera, E. Tovar, M. Llamas-Nistal, G. Diaz, J. Peire, and M. Castro, "Common Multidisciplinary Prototypes of Remote Laboratories in the Educational Curricula of Electrical \& Computer Engineering," presented at the ASEE Annual Conference San Antonio, Texas, 2012.

[15] M. Tawfik, E. S. Cristobal, A. Pesquera, R. Gil, S. Martin, G. Diaz, J. Peire, M. Castro, R. Pastor, S. Ros, and R. Hernandez, "Shareable educational architectures for remote laboratories," in Technologies Applied to Electronics Teaching (TAEE), 2012, 2012, pp. 122127.

[16] E. Sancristobal, M. Castro, S. Martin, M. Tawkif, A. Pesquera, R. Gil, G. Diaz, and J. Peire, "Remote labs as learning services in the educational arena," in IEEE Global Eng. Educ. Con. (EDUCON) 2011, pp. 1189-1194.

[17] E. Sancristobal, A. Pesquera, S. Martin, R. Gil, M. Tawfik, M. Castro, E. Ruiz, G. Diaz, A. Colmenar, and J. Carpio, "Challenges of applying online learning tools in distance learning courses," in Global Engineering Education Conference (EDUCON), 2012 IEEE, 2012, pp. 17.

[18] E. Sancristobal, A. Pesquera, M. Tawfik, M. Latorre, F. Garcia-Loro, R. G. E. Ruiz, S. Martín, G. Diaz, A. Colmenar, and M. Castro, "Learning Management Systems and Online Labs within Virtual Worlds," presented at the Remote Eng. \& Virtual Instrum. (REV) 2011, Brasov, Romania, 2011.

[19] C. Maier and M. Niederstätter, "Lab2go - A Repository to Locate Online Laboratories," Int. J. of Online Eng. (iJOE), vol. 6, pp. 12-17, 2010.

[20] (2012, October 30). MIT iCampus: iLabs. Available: http://icampus.mit.edu/ilabs/

[21] V. J. Harward, J. A. del Alamo, S. R. Lerman, P. H. Bailey, J. Carpenter, K. DeLong, C. Felknor, J. Hardison, B. Harrison, I. Jabbour, P. D. Long, M. Tingting, L. Naamani, J. Northridge, M. Schulz, D. Talavera, C. Varadharajan, W. Shaomin, K. Yehia, R. Zbib, and D. Zych, "The iLab Shared Architecture: A Web Services Infrastructure to Build Communities of Internet Accessible Laboratories," Proceedings of the IEEE, vol. 96, pp. 931-950, 2008.

[22] (2012, January 1). Labshare - Home. Available: http://www.labshare.edu.au/

[23] D. Lowe, S. Conlon, S. Murray, L. Weber, M. de la Villefromoy, E. Lindsay, A. Nafalski, W. Nageswaran, and T. Tang, "Labshare: Towards Cross- Institutional Laboratory Sharing," in Internet Accessible Remote Laboratories: Scalable E-Learning Tools for Engineering and Science Disciplines, ed: IGI Global, 2012, pp. 453-467.

[24] D. Lowe, S. Murray, L. Weber, and M. d. 1. Villefromoy, "LabShare: Towards a National Approach to Laboratory Sharing," presented at the 20th Australasian Association for Engineering Education Conference, University of Adelaide, 2009. 
[25] (2012, October 30). WebLab Deusto. Available: https://www.weblab.deusto.es/

[26] P. Orduña, J. Irurzun, L. Rodriguez-Gil, J. Garcia-Zubia, F. Gazzola, and D. López-de-Ipiña, "Adding New Features to New and Existing Remote Experiments through their Integration in WebLab-Deusto," International Journal of Online Engineering (iJOE), vol. 7, pp. 33-39, 2011.

[27] P. Orduña, J. Irurzun, L. Rodriguez-Gil, J. García-Zubia, and D. López-de-Ipiña, "Reusing requirements among remote experiments for their development and integration under WebLab-Deusto," presented at the Remote Eng. \& Virtual Instrum. (REV) 2011, Brasov, Romania, 2011.

[28] M. Tawfik, E. Sancristobal, S. Martín, C. Gil, A. Pesquera, P. Losada, G. Díaz, J. Peire, M. Castro, J. García-Zubia, U. Hernández, P. Orduña, I. Angulo, M. C. C. Lobo, M. A. Marques, M. C. Viegas, and G. R. Alves, "VISIR: Experiences and Challenges," Int. J. of Online Eng. (iJOE), vol. 8, pp. 25-32, February 20122012. 